\title{
EFEKTIVITAS PELATIHAN HARDINESS UNTUK MENINGKATKAN SIKAP TANGGUH DALAM MENYELESAIKAN MASALAH
}

\author{
Joice Mailoa1 \\ Aulia Ramdani
}

\author{
Fakultas Psikologi, Universitas Surabaya
}

\section{Keywords/Kata kunci}

coping strategies,

employee, hardiness,

stressor

ABSTRACT/ABSTRAK:

Any changes in the system of an organization could be stressful. Having hardiness would be important to deal with a problem. This study aims to seek out the effectiveness of hardiness training in improving problemsolving. A quasi-experimental design with one group pretest-post test design was applied. There were sixteen employees of various organizational divisions enrolled in this study. Data were collected before and after the six-session of hardiness training using the Brief COPE scale and the Dispositional Resilience Scale (DRS-15) developed by Bertone. Results from the Wilcoxon signed-rank test showed that there was no significant difference in the attitude of the effectiveness of problem-solving among employees before and after training $(p>0,05)$. However, there were differences in knowledge of understanding hardiness before and after training. ( $p=.002, p>0,05)$. It can be concluded that hardiness training could increase the knowledge about hardiness; but not the attitude toward problem-solving.
\end{abstract}

karyawan,

ketangguhan, stressor, strategi coping

Setiap perubahan dalam sistem organisasi dapat membuat stres bagi sebagian orang. Memiliki sifat tahan banting menjadi penting dalam menghadapi suatu masalah. Penelitian ini bertujuan untuk mengetahui efektivitas pelatihan hardiness dalam meningkatkan pemecahan masalah. Penelitian ini menggunakan desain kuasi eksperimen dengan desain one group prates-paskates. Enam belas karyawan dari berbagai divisi organisasi Yayasan Sosial dilibatkan dalam penelitian ini. Data dikumpulkan sebelum dan setelah enam sesi pelatihan hardiness menggunakan skala Brief COPE dan Dispositional Resilience scale (DRS15) yang dikembangkan Bertone. Hasil dari uji Wilcoxon signed rank-test menunjukkan bahwa tidak ada perbedaan yang signifikan dalam sikap pemecahan masalah di antara karyawan sebelum dan sesudah pelatihan ( $>$ > 0,05). Namun, ada perbedaan pengetahuan dalam memahami hardiness sebelum dan sesudah pelatihan. $(p=0,002, p>0,05)$. Disimpulkan bahwa pelatihan hardiness dapat meningkatkan pengetahuan tentang hardiness; tetapi tidak dapat meningkatkan sikap tangguh dalam menyelesaikan masalah.

\footnotetext{
${ }^{1}$ Korespondensi mengenai artikel ini dapat dilakukan melalui: joicemailoa@gmail.com
} 
Strategi koping atau penyelesaian masalah merupakan proses untuk mengelola tuntutan internal dan eksternal dari situasi yang tidak menyenangkan (Taylor, 2011). Strategi koping yang efektif akan menghasilkan kepuasan terhadap pekerjaan dan performa kerja yang lebih tinggi serta dapat menurunkan intensitas keluar-masuk dalam organisasi (Cash \& Dianne, 2011). Sebaliknya, penyelesaian masalah yang tidak efektif berdampak pada lingkungan kerja yang penuh tekanan dan kontrol diri yang rendah (Anshel et al., 2013). Strategi koping berfungsi untuk mengubah situasi yang menyebabkan timbulnya stres atau mengatur reaksi emosional yang muncul karena suatu masalah. Individu yang tidak mampu mengatasi stres atau tekanan akan cenderung menghindar dari tekanan tersebut dengan berbagai cara. Kondisi yang menekan atau tidak menyenangkan dapat berdampak pada kesehatan fisik dan kondisi psikologis individu (Cash \& Dianne, 2011).

Dalam mengatasi masalah, Biasanya individu akan mencoba menggunakan koping yang berfokus pada masalah terlebih dahulu. Jika gagal, maka individu akan mencoba untuk menggunakan strategi problem-focused coping lainnya dan jika kembali gagal maka akan mencoba strategi koping yang terfokus pada emosi (Brannon et al., 2014).

Problem-focused coping dan emotionfocused coping memiliki dua fungsi yang berbeda tetapi keduanya memfasilitasi dan menghambat satu sama lain dalam proses penyelesaian masalah serta dapat lebih bermanfaat daripada yang lain dalam situasi yang berbeda (Lazarus \& Folkman, 1984). Misalnya emotional focused coping sebenarnya lebih banyak digunakan untuk jenis permasalahan yang berada di luar kontrol atau kendali individu tersebut. Oleh sebab itu, penggunaan strategi koping yang efektif akan mempermudah individu di dalam proses penyelesaian masalah dalam kehidupan sehari-hari termasuk pekerjaan.

Salah satu stresor dalam pekerjaan yakni adanya perubahan sistem organisasi yang berdampak pada tugas dan pekerjaan karyawan. Tekanan dari perubahan sistem ini dirasakan oleh salah satu yayasan nonprofit yang bergerak di berbagai bidang yakni pendidikan, sosial dan keagamaan di Surabaya. Sebagai yayasan yang sudah berdiri sejak 28 tahun yang lalu sedang dalam proses mengadakan berbagai perubahan sistem sesuai dengan konteks zaman yang semakin berkembang. Misalnya pengadaan nilai organisasi, memiliki sistem rekrutmen dan proses audit karyawan.

Yayasan ini memiliki beragam usia karyawan dari yang muda hingga lanjut usia. Beberapa karyawan yang sudah lanjut usia bekerja sejak awal yayasan mulai dibentuk sehingga terdapat perbedaan generasi yang berdampak pada penyelesaian masalah dalam pekerjaan sehari-hari. Hal ini tampak ketika adanya ide-ide atau gagasan yang dimunculkan oleh karyawan yang muda namun tidak disetujui oleh atasan atau rekan kerja yang tergolong tua. Adanya perbedaan pendapat yang tidak diselesaikan membuat karyawan cenderung menghindari permasalahan yang ada. Berikut hasil wawancaranya:

"karena kerjanya dengan beberapa yang udah senior, jadi ya gitu.. kan ada pepatah yang bilang, kalau sudah tua itu kaya besi, susah untuk dibentuk. Susah kalau mau ngapangapain, bingung juga.. misalnya ketika ada ide mau ngadain program ini, program itu atasan oke, tapi ketika berhadapan dengan setiap staf merekanya gak mau apalagi yang sudah agak senior".

(A, 27/03/19) 
Menurut Bapak A yang merupakan salah satu kepala divisi $\mathrm{X}$, perbedaan usia pada tiap karyawan menjadi tantangan ketika melakukan koordinasi. Selain itu, kasus Bapak B salah satu karyawan muda yang merespon konflik dengan mencari dukungan pada kepala divisi lain. Berikut hasil wawancaranya:

"Terkadang ada karyawan yang ketika melaksanakan tugas yang diberikan tidak berkoordinasi dengan atasan divisinya karena merasa tidak cocok, ia malah meminta dukungan kepada kepala divisi lain sehingga atasan dan bawahan ini menjadi salah paham"

(B, 27 Maret 2019)"

Selain itu, adanya perasaan akan beban kerja yang berlebihan. Namun respon yang ditunjukkan oleh individu adalah cenderung untuk menerima dan tidak melakukan koordinasi dengan atasan. Kondisi tersebut berdampak pada respon fisik seperti kesulitan tidur. Berikut hasil wawancaranya:

"Kadang stres sih soalnya ngerasa beban kerja yang dikasih juga terlalu berat dari yang seharusnya. Mau gimana lagi diterima aja... kadang orang rumah jadi ngeluh juga karena sikap yang jadi menjengkelkan. Kadang juga ngerasa kurang tidur walaupun sudah tidur (C, 27 Maret 2019)".

Selain itu, ketika melakukan wawancara dengan salah satu kepala divisi yayasan, Ia juga mengungkapkan kebiasaan bergosip oleh beberapa karyawan. Misalnya beredar gosip mengenai karyawan muda yang naik jabatan dalam rentang kerja yang cepat. Bapak C merespon kondisi tersebut dengan prihatin karena nilai saling menghargai dan mengasihi yang dianut oleh yayasan tidak semuanya diterapkan oleh karyawan.

Berdasarkan hasil wawancara awal yang telah dilakukan tersebut, dapat disimpulkan bahwa penyelesaian masalah yang dilakukan oleh beberapa karyawan masih belum efektif. Penyelesaian yang dilakukan selama ini adalah menghindar dan mengabaikan permasalahan walaupun mereka merasakan dampak yang tidak menyenangkan. Selain itu, penyelesaian masalah yang kurang efektif menimbulkan efek timbal balik pada proses perubahan yang ada. Oleh karena itu, perlu adanya upaya untuk meningkatkan efektivitas penyelesaian masalah pada karyawan di yayasan.

Salah satu upaya yang dapat dilakukan untuk membuat individu memilih penyelesaian masalah yang efektif yakni dengan memberikan pelatihan ketangguhan (hardiness) (Cash \& Dianne, 2011). Ketangguhan merupakan salah satu karakteristik kepribadian yang memiliki kemampuan untuk secara efektif mengelola situasi yang penuh tekanan (Kobasa, 1982). Ketangguhan dipahami sebagai sifat dari kepribadian dan kepribadian dinilai relatif stabil sepanjang waktu. Tetapi Funder (1991) berpendapat bahwa sifat dapat muncul dari interaksi antara genetik dan pengalaman individu. Dengan demikian, melalui fasilitasi kondisi dan pengalaman, ada kemungkinan bahwa beberapa sifat seperti ketangguhan dapat dipelajari dan dikembangkan (Algoe \& Fredrickson, 2011; Maddi, 2008; Maddi et al., 2009).

Ketangguhan menjadi penting dimiliki setiap individu karena memfasilitasi ketahanan atau resiliensi di bawah tekanan dan memberikan dampak positif terhadap penyelesaian masalah yang efektif (Maddi et al., 2013). Individu yang tangguh akan lebih banyak menggunakan penyelesaian masalah yang berfokus pada usaha dibandingkan menghindari dan membiarkan permasalahan tersebut (Kobasa, 1982; 
Maddi, 2008). Penelitian lain yang juga mendukung dilakukan Cash \& Dianne, (2011), ketangguhan memiliki korelasi positif dengan problem focused coping dan socially supported, artinya semakin tinggi tingkat ketangguhan individu maka semakin tinggi individu melakukan usaha, dalam hal ini ialah problem focused coping dan socially supported dibandingkan melakukan penghindaran (avoidance coping).

Selain itu, ketangguhan memiliki hubungan positif dengan keyakinan terhadap peristiwa dalam hidup yang dikendalikan diri sendiri (locus of control internal) sehingga memiliki korelasi yang rendah dengan stres dan gangguan fisik dibandingkan individu yang percaya bahwa peristiwa dalam hidupnya dikendalikan oleh kekuatan di luar dirinya (locus of control external).

Ketangguhan juga memandang perubahan sebagai suatu hal yang normal sehingga dapat menjadi peluang untuk berkembang dan bersifat terbuka dan fleksibel terhadap suatu perubahan (Kobasa et al., 1982). Oleh sebab itu, melalui pelatihan Be a Hardy Person: "Grow through what you go through", dapat membantu meningkatkan ketangguhan karyawan sehingga berdampak pada efektivitas penyelesaian masalah sehari-hari dan pekerjaan. Berdasarkan pemaparan dalam latar belakang penelitian ini, maka hipotesis penelitian ini adalah terdapat perbedaan efektivitas pemilihan penyelesaian masalah pada karyawan antara sebelum dan sesudah diberikan pelatihan ketangguhan.

\section{METODE PENELITIAN}

\section{Desain Penelitian}

Penelitian ini merupakan penelitian quasi-experiment dengan menggunakan nonrandomized one group prates paskates design. Desain tersebut dipilih dengan pertimbangan pada penelitian ini tidak memungkinkan dilakukan randomisasi untuk membagi partisipan dalam kelompok eksperimen dan kelompok kontrol (Seniati et al., 2011). Pada desain ini hanya terdapat kelompok eksperimen karena keterbatasan jumlah partisipan yang dapat mengikuti pelatihan.

Penelitian ini tidak menggunakan kelompok pembanding melainkan menggunakan pengukuran awal guna mengetahui perbedaan pemilihan jenis penyelesaian masalah antara sebelum dan sesudah pelatihan diberikan. Berikut desain yang digunakan pada penelitian ini:

\section{NR $01-X-02$}

Gambar 1. Desain Penelitian

Keterangan:

NR : Non-Random

01 : Pengukuran I (Awal)

$\mathrm{X}$ : Pelatihan Ketangguhan

02 : Pengukuran II (Setelah Intervensi) 


\section{Subjek Penelitian}

Partisipan dalam penelitian ini berjumlah 16 orang dengan rentang usia 25 60 tahun diambil dengan menggunakan teknik sampling aksidental (pengambilan sampel sesuai ketersediaan subjek). Dengan total partisipan berjumlah 35 orang, namun hanya sebanyak 16 orang peserta yang datanya dapat digunakan karena dalam proses pelaksanaan pelatihan, terdapat hal lain yang harus dilakukan oleh sebagian peserta. Sebagian peserta adalah laki-laki berjumlah 9 orang (56\%) dan perempuan berjumlah 7 orang (44\%).

Selain itu, keseluruhan peserta berasal dari divisi yang berbeda-beda yakni 3 peserta (19\%) dari divisi keuangan, 3 peserta (19\%) dari divisi sosial-humanis, 2 peserta (12\%) dari divisi mental spiritual, 3 peserta (18\%) dari divisi kemitraan, 2 peserta (12\%) dari divisi HRD, 1 peserta (6\%) dari divisi logistik dan 2 peserta yang merupakan 2 relawan (13\%) dari rumah manula dan panti asuhan anak.

Peserta juga tidak sedang mengikuti program psikologis lain selama pelatihan diberikan; dan bersedia mengisi informed consent sebagai bukti tertulis kesediaan terlibat dalam penelitian.

\section{Metode Pengumpulan Data}

Pengumpulan data dalam penelitian ini dilakukan menggunakan data kualitatif dan pendekatan kuantitatif. Data kualitatif berupa wawancara dan observasi, serta data kuantitatif diperoleh dari skala penyelesaian masalah dan ketangguhan. Pengukuran evaluasi penyelesaian masalah dilakukan dengan menggunakan translasi skala Brief COPE (Carver, 1997) yang berbentuk Likert dengan empat pilihan jawaban yakni (1) saya belum pernah melakukannya; (2) saya sedikit melakukannya; (3) saya cukup sering melakukan; (4) saya sangat sering melakukannya.
Hasil dari uji coba alat ukur menunjukkan bahwa alat ukur tersebut memiliki coeficient alpha sebesar 0,37-0,93, dengan pengecualian pada aspek mental disengagement yang memiliki coeficient alpha sebesar 0,59. Di luar aspek tersebut, aspek yang lain memiliki coefiecient alpha $>0,70$ dengan rata-rata 0,79 . Hal ini menunjukkan bahwa alat ukur tersebut reliabel dalam mengukur strategi koping. Skala terdiri atas 28 butir pertanyaan yang mengukur penggunaan strategi koping seperti active coping, planning, positive refreaming, acceptance, humor, religion, using emotional support, using instrumental support, self distraction (mental disangagement), denial, venting substance use dan behavioral disengagement.

Sedangkan untuk pengukuran evaluasi ketangguhan menggunakan skala Dispositional Resilience Scale (DRS-15) yang disusun Bartone, (1995) dengan 15 butir pertanyaan. Skala ini berbentuk Likert dengan 4 pilihan jawaban yakni (1) sama sekali tidak benar, (2) sedikit benar, (3) cukup benar dan (4) sangat benar. Masingmasing komponen dari ketangguhan memiliki koefisien reliabilitas sebesar 0,77 untuk aspek komitmen, 0,71 untuk aspek kontrol dan 0,70 untuk aspek chalenge. Hal ini menunjukkan bahwa skala ketangguhan yang digunakan memiliki reliabilitas yang baik.

Kedua skala tersebut diberikan sebelum sesi pertama dan setelah sesi terakhir pelatihan. Selain itu dilakukan evaluasi perilaku berupa tindak lanjut (follow-up) satu minggu setelah intervensi diberikan. Evaluasi perilaku dilakukan dengan melihat check-list yang berisi indikator perilaku efektivitas penyelesaian masalah. 


\section{Prosedur Intervensi}

Sebelum pelaksanaan intervensi, peneliti melakukan pengambilan data untuk menganalisis kebutuhan dari yayasan sosial ini. Proses pengambilan data dengan menggunakan teknik wawancara selama bulan Maret - April 2019 hingga presentasi akhir pada pihak yayasan untuk melakukan konfirmasi terkait analisis kebutuhan yang ditemukan.

Pelatihan yang diberikan terdiri atas enam sesi, berikut ini rincian tujuan dan kegiatannya dipaparkan dalam tabel 1 :

Tabel 1. Tujuan dan Rencana Kegiatan

\begin{tabular}{ll}
\hline Waktu Pertemuan & Tujuan dan Rencana Kegiatan \\
\hline Sesi 1: & Pada sesi pertama ini akan membahas terkait gambaran ketangguhan dan strategi \\
Pemahaman & koping. Tujuan umum dari sesi ini adalah: \\
Ketangguhan \& & - Peserta mengetahui arah dan tujuan pelatihan; \\
Strategi Koping & - Peserta mengetahui konsep ketangguhan dan kaitannya dengan strategi \\
& koping; \\
& Selain itu terdapat beberapa tujuan khusus diantaranya: \\
& - Peserta mengetahui dan menyadari kelebihan dan kelemahan diri; \\
& - Peserta mengetahui keterkaitan ketangguhan dengan strategi koping; \\
& - Peserta mengetahui arti dan dampak ketangguhan dalam menghadapi \\
& - Permasalahan sehari-hari \\
& Peserta memahami dan menyadari pentingnya ketangguhan dalam kehidupan \\
& Rencana Kegiatan: \\
& - Refleksi, diskusi dan sharing mengenai gambaran ketangguhan melalui \\
& tayangan video \\
& - Menuliskan kelebihan dan kekurangan yang dimiliki pada lembar kerja. \\
& Sharing dalam kelompok terkait kelebihan dan kekurangan yang dimiliki serta \\
& meminta umpan balik terkait kelebihan/kekurangan yang diketahui oleh rekan \\
& - Perja. \\
& pribadi yang tangguh.
\end{tabular}

Waktu Pertemuan Tujuan dan Rencana Kegiatan

Sesi 2: $\quad$ Pada sesi ke dua, tujuan secara umum untuk memahami aspek kontrol dalam tim

Kontrol dan $\quad$ kerja. Beberapa jabaran tujuan khusus diantaranya:

Peranan dalam - Peserta mengetahui pengertian aspek kontrol dalam ketangguhan;

Tim Kerja - Peserta menyadari pentingnya kontrol dalam diri serta peranannya dalam tim kerja

- Peserta dapat menerapkan kontrol dalam tim kerja

Rencana kegiatan yang disusun diantaranya:

- Penyampaian materi mengenai kontrol dalam ketangguhan

- Bermain tower menara dan mengisi lembar TTS, kemudian melakukan diskusi serta refleksi terkait kontrol diri yang dimiliki masing-masing pribadi dan penerapan dalam tim saat bermain.

Sesi 3:

Komitmen Diri
Tujuan umum dari sesi ke tiga ialah mengetahui aspek komitmen dalam ketangguhan. Oleh sebab itu, beberapa tujuan khusus dari sesi ini adalah:

- Peserta mengetahui arti dari komitmen;

- Peserta dapat mengidentifikasi komitmen diri dalam bekerja;

- Peserta dapat mengetahui dan menyadari pentingnya komitmen dalam tim.

Rencana kegiatan yang disusun diantaranya: 
- Penayangan video terkait pentingnya komitmen, diskusi dan sharing mengenai video;

- Memberikan materi terkait komitmen;

- Mengisi lembar kerja mengenai sense of purpose yang akan membantu identifikasi motivasi dalam bekerja dan berpengaruh terhadap penyelesaian masalah.

Sesi 4: $\quad$ Tujuan umum dari sesi ke empat yakni mengetahui aspek komitmen dalam tim.

Kita Satu Oleh sebab itu, beberapa tujuan khusus dari sesi ini adalah:

- Peserta memahami pentingnya keterlibatan dalam tim

- Peserta mengetahui dan menyadari pentingnya komitmen dalam tim

Rencana kegiatan yang akan dilakukan diantaranya:

- Melakukan kajian ulang terhadap pemberian materi sesi 1-3 pada hari sebelumnya;

- Penjelasan materi dan penayangan video mengenai komitmen kemudian melakukan diskusi dan sharing dalam kelompok.

- Menuliskan peran dalam divisi dan perasaan yang menyertai ketika bekerja.

Sesi 5:

Menghadapi

Perubahan
Tujuan umum dari sesi ini adalah peserta memahami pentingnya menghadapi

tantangan. Secara spesifik beberapa tujuan khusus diantaranya:

- Peserta mengetahui perubahan merupakan suatu tantangan

- Peserta mengetahui dan menyadari pentingnya menghadapi suatu tantangan

- Peserta dapat menghadapi perubahan sebagai suatu tantangan.

Rencana kegiatan:

- Secara berkelompok, setiap peserta akan bermain dua permainan yang berisi tantangan yakni menggambar dengan tangan yang tidak biasa, serta menemukan benda di dalam ruangan sesuai instruksi

- Merefleksikan hal-hal yang dipelajari melalui permainan yang berkaitan dengan perubahan sebagai tantangan.

Sesi 6:

Berubah untuk

Lebih Baik
Pada sesi terakhir ini, peserta diharapkan dapat mengetahui dan memahami pentingnya menjadi pribadi yang tangguh serta dapat membuat action plan ketika berhadapan dengan permasalahan. Oleh sebab itu, kegiatan yang dilakukan adalah menjelaskan ketiga aspek pribadi yang tangguh dan membuat action plan dengan menggunakan metode SMART.
Pelatihan dilakukan selama dua hari yakni 17 dan 18 Mei 2019 dengan durasi 90 menit untuk masing-masing sesi. Pada hari pertama terdiri atas sesi pertama hingga ketiga. Pada hari kedua diberikan sesi ke empat hingga enam. Pelatihan yang diberikan mengacu pada aspek-aspek ketangguhan yakni kontrol, komitmen dan tantangan.

Berdasarkan tabel 1, pada sesi pertama dibahas gambaran teori ketangguhan dan penyelesaian masalah yang akan dipelajari dalam dua hari pelaksanaan pelatihan. Dalam sesi ini peneliti menjelaskan pentingnya ketangguhan dan kaitannya terhadap penyelesaian masalah yang efektif. Oleh sebab itu, sesi pertama dimulai dengan mengenal dan mengidentifikasi diri melalui kelebihan dan kelemahan diri sendiri dalam menyelesaikan permasalahan. Ada proses diskusi dalam kelompok sehingga rekan kerja dapat memberikan masukan terkait kelebihan dan hal-hal yang masih perlu dikembangkan.

Pada sesi kedua, peserta diberi penjelasan mengenai aspek pertama pembentuk pribadi tangguh yakni kontrol melalui permainan "tower-menara" yang dibangun dengan menggunakan kartu. Penekanan pada sesi ini ialah peserta diajak 
untuk merefleksikan perannya dalam penyelesaian masalah. Hal ini menjadi penting karena berdasarkan analisis kebutuhan yang dilakukan, beberapa karyawan menganggap tidak memiliki andil dalam permasalahan yang terjadi di dalam pekerjaan sehingga cenderung untuk mengabaikan dan menghindari.

Pada sesi ketiga dan keempat, peserta diberi materi mengenai aspek kedua pembentuk ketangguhan yakni komitmen melalui lembar kerja yang dibagikan. Peserta mengidentifikasi komitmen terhadap diri dan pekerjaan serta organisasi yang akan membantu dalam merefleksikan penerapan komitmen yang sudah dilakukan ketika bekerja. Komitmen menjadi suatu hal yang penting karena dapat membantu para peserta pelatihan untuk terlibat penuh dalam kegiatan organisasi dan turut berdampak pada proses penyelesaian masalah ketika berada dalam keterlibatan tersebut. Berdasarkan analisis kebutuhan, karyawan memiliki nilai-nilai pribadi yang berbeda dan tidak sesuai dengan organisasi sehingga berdampak pada komitmen ketika bekerja. Oleh sebab itu, melalui sesi ini para peserta dapat menyadari komitmen diri dalam penerapannya terhadap organisasi.

Pada sesi kelima, diajarkan mengenai aspek terakhir dari ketangguhan yakni kemampuan dalam menghadapi tantangan khususnya ketika berhadapan dengan perubahan dalam organisasi. Pada sesi ini, digunakan metode permainan "menulis dengan tangan yang tidak biasa" untuk merefleksikan dan mengambil nilai mengenai sikap ketika menghadapi perubahan.

Sesi terakhir ditutup dengan melakukan rencana yang spesifik untuk mencapai tujuan yang diinginkan yakni menjadi pribadi yang tangguh sehingga dapat efektif dalam menyelesaikan masalah dengan menggunakan metode SMART (Specific, Measurable, Achivable, Relevant \&Time Bound).

\section{Teknik Analisis}

Analisis data kuantitatif yang dilakukan pada penelitian ini yaitu uji asumsi, uji deskripsi dan uji hipotesis dengan paired sample t-test apabila memenuhi uji asumsi normalitas dan menggunakan statistik nonparametrik khususnya uji wilcoxon apabila tidak memenuji uji asumsi normalitas

Uji deskripsi dilakukan untuk mendapatkan gambaran umum hasil penelitian dam uji hipotesis dilakukan untuk melihat efektivitas pelatihan ketangguhan dalam meningkatkan strategi pemilihan penyelesaian masalah. Analisis data menggunakan bantuan SPSS versi 16.00 .

\section{HASIL PENELITIAN}

Partisipan dalam pelatihan ini berjumlah 16 orang. Penjabaran mengenai peserta dapat dilihat pada tabel 2 : 
Tabel 2. Deskripsi Peserta Pelatihan

\begin{tabular}{cccclll}
\hline No. & $\begin{array}{c}\text { Nama } \\
\text { Peserta }\end{array}$ & Usia & $\begin{array}{c}\text { Jenis } \\
\text { Kelamin }\end{array}$ & Jabatan & \multicolumn{1}{c}{ Divisi } \\
\hline 1 & A & 25 & Perempuan & Staf & Keuangan \\
2 & B & 48 & Perempuan & Relawan & Rumah Manula \\
3 & C & 54 & Perempuan & Staf & Sos-Hum \\
4 & D & 50 & Laki-Laki & Pembina Anak & Panti Anak \\
5 & E & 23 & Laki-Laki & Staf & Mental-Spiritual \\
6 & F & 18 & Perempuan & Staf Admin Sekretariat & HRD \\
7 & G & 27 & Laki-Laki & Admin & HRD \\
8 & H & 37 & Perempuan & Admin & Logistik \\
9 & I & 30 & Laki-Laki & Kepala Divisi & Keuangan \\
10 & J & 30 & Laki-Laki & Staf & Keuangan \\
11 & K & 31 & Laki-Laki & Admin & Kemitraan \\
12 & L & 29 & Laki-Laki & Manager & Kemitraan \\
13 & M & 31 & Laki-Laki & Staf & Kemitraan \\
14 & N & 60 & Perempuan & Staf & Mental-Spiritual \\
15 & O & 52 & Laki-Laki & Kepala Divisi & Sos-Hum \\
16 & P & 30 & Perempuan & Staf & Sos-Hum \\
\hline
\end{tabular}

\section{Hasil Analisis Data}

Sebagai upaya memastikan tidak ada kesalahan dalam mengambil sampel maka dilakukan uji asumsi yakni normalitas.
Hasil uji normalitas dapat dilihat pada tabel 3 .

Tabel 3. Uji normalitas Jenis Koping Strategi

\begin{tabular}{cccccc}
\hline \multirow{2}{*}{$\begin{array}{c}\text { Strategi } \\
\text { Koping }\end{array}$} & \multirow{2}{*}{ PFC } & \multicolumn{3}{c}{ Shapiro-Wilk } & \multirow{2}{*}{ Keterangan } \\
\cline { 3 - 5 } & & Statistic & Df & Sig & \\
\hline \multirow{2}{*}{ PFC } & Pra tes & 0,882 & 16 & 0,042 & Tidak Normal \\
\cline { 2 - 5 } & Paska tes & 0,892 & 16 & 0,060 & Normal \\
\hline \multirow{2}{*}{ EFC } & Pra tes & 0,815 & 16 & 0,004 & Tidak Normal \\
\cline { 2 - 5 } & Paska tes & 0,908 & 16 & 0,110 & Normal \\
\hline \multirow{2}{*}{ SS } & Pra tes & 0,955 & 16 & 0,577 & Normal \\
\cline { 2 - 5 } & Paska tes & 0,906 & 16 & 0,100 & Normal \\
\hline \multirow{2}{*}{ AC } & Pra tes & 0,968 & 16 & 0,803 & Normal \\
\cline { 2 - 5 } & Paska tes & 0,953 & 16 & 0,540 & Normal \\
\hline
\end{tabular}

Hasil uji asumsi pada penelitian ini menggunakan shapiro wilk menunjukkan bahwa data problem focused coping (PFC) yang digunakan sebelum pelatihan bersifat tidak normal $($ sig<0,05) dan setelah pelatihan bersifat normal (sig $>0,05)$. Hasil pada analisis tabel 3 menunjukkan data prates memiliki distribusi atau sebaran data yang tidak normal dan data paskates memiliki distribusi atau sebaran data yang normal. Kemudian peneliti melakukan uji statistik non-parametrik yaitu Wilcoxon untuk melihat apakah ada perbedaan sebelum dan sesudah dilaksanakan pelatihan, diperoleh hasil signifikansi sebesar 0,842 ( $>0,05)$. Hal ini menunjukkan tidak ada perbedaan skor sikap problem focused coping secara signifikan sebelum dan setelah pelatihan.

Analisis berikutnya dilakukan untuk menguji normalitas data emotional focused coping (EFC). Berdasarkan uji normalitas 
terhadap data prates maka diperoleh nilai sig $0,004 \quad(<0,05)$ dan hasil paskates diperoleh nilai sig 0,110 $(>0,05)$. Hasil pada analisis data di atas menunjukkan data prates memiliki distribusi atau sebaran data yang tidak normal dan data paskates memiliki distribusi atau sebaran data yang normal. Kemudian peneliti melakukan uji statistik non-parametrik yaitu Wilcoxon untuk melihat apakah ada perbedaan sebelum dan sesudah dilaksanakan pelatihan, didapati hasil nilai signifikansi sebesar 0,265 ( $>>0,05)$. Hal ini menunjukkan tidak ada perbedaan skor sikap emotional focused coping secara signifikan sebelum dan setelah dilakukan pelatihan.

Jenis penyelesaian masalah selanjutnya ialah socially supported. Berdasarkan uji normalitas terhadap data prates maka diperoleh nilai sig $0,577(>0,05)$ dan hasil paskates diperoleh nilai sig 0,110 $(>0,05)$. Hasil pada analisis data di atas menunjukkan data prates dan data paskates memiliki distribusi atau sebaran data yang normal. Selanjutnya, peneliti melakukan uji statistik parametrik yaitu paired sample $t$ test untuk melihat perbedaan sebelum dan sesudah dilaksanakan pelatihan. Diperoleh signifikansi sebesar 0,664 $(p>0,05)$. Hal ini menunjukkan tidak ada perbedaan skor sikap socially supported secara signifikan sebelum dan setelah dilakukan pelatihan.

Selanjutnya pada avoidance coping (AC), hasil pada analisis data di atas menunjukkan data prates dan data paskates memiliki distribusi atau sebaran data yang normal. Kemudian peneliti melakukan uji statistik parametrik yaitu paired sample $t$ test untuk melihat perbedaan sebelum dan sesudah dilaksanakan pelatihan. Diperoleh hasil signifikansi sebesar 0,085 ( $p>0,05$ ). Hal ini menunjukkan tidak ada perbedaan skor sikap avoidance coping secara signifikan sebelum dan setelah dilakukan pelatihan.

Berdasarkan hasil analisis pada empat jenis strategi koping yang dilakukan, menunjukkan tidak adanya peningkatan sikap dalam efektivitas pemilihan strategi koping antara sebelum dan sesudah diberi pelatihan ketangguhan. Selanjutnya, meskipun pelatihan ketangguhan tidak efektif dalam meningkatkan sikap terkait efektivitas penyelesaian masalah, namun pelatihan ini cukup efektif untuk meningkatkan pengetahuan peserta mengenai ketangguhan. Berikut tabel 4 yang menjelaskan perbedaan rata-rata dan hasil uji beda yang dilakukan:

Tabel 4. Perbedaan Mean

\begin{tabular}{cc}
\hline Knowledge & Mean \\
\hline Prates & 70.1012 \\
\hline Paskates & 82.8131 \\
\hline
\end{tabular}

Tabel 5. Uji Beda Wilcoxon

\begin{tabular}{lll}
\hline Aspek & Z-Score & Signifikansi \\
\hline Knowledge & $-3,093$ & 0,002 \\
\hline
\end{tabular}

Berdasarkan hasil lembar observasi peserta dan pengamatan pada lembar kerja pelatihan, pada sesi pertama pemahaman mengenai ketangguhan, semua peserta aktif berdiskusi dan menuliskan kelebihan serta kekurangan diri ketika berhadapan dengan masalah. Selain menuliskan secara pribadi, rekan sekelompok juga memberikan masukan terkait kelebihan dan kekurangan diri sehingga mempermudah untuk identifikasi diri. Beberapa peserta mendapat 
respon yang positif karena akhirnya lebih mengenal diri sendiri.

Pada sesi kedua yakni peranan kontrol diri dan kontrol dalam tim, materi dibagikan dalam metode permainan dan diskusi kelompok. Semua peserta mengalami beberapa kondisi yakni memiliki kendali atau kontrol atas menara yang dibangun dan kesempatan dalam menyelesaikan masalah atau kasus dalam diskusi kelompok. Metode permainan dan diskusi membuat beberapa peserta menyadari bagaimana diri sendiri dan orang lain ketika diatur untuk memiliki keyakinan dan berupaya untuk menyelesaikan masalah. Di sisi lain, beberapa peserta menyadari bagaimana respon ketika diatur untuk bersikap menyerah dan pasrah (tidak memiliki kontrol) ketika menghadapi masalah. Munculnya kesadaran serta pemahaman mengenai kontrol diri dan kontrol di dalam tim, peserta berusaha melakukan tindakan penyelesaian masalah yang efektif.

Pada sesi komitmen diri, peserta mengisi lembar kerja identifikasi tujuan dalam bekerja, kesesuaian pekerjaan dengan nilai pribadi sehingga akan memunculkan komitmen dan membantu dalam proses penyelesaian masalah. Sebagian besar memiliki nilai yang berbeda dengan tujuan bekerja sehingga mengalami hambatan dalam berkomitmen. Namun secara keseluruhan, peserta mulai mengetahui dan menyadari kesenjangan antara tujuan dan nilai dalam bekerja sehingga dapat menjadi awal yang baik dalam memperbarui komitmen masing-masing peserta dalam bekerja.

Sesi "kita satu" yakni komitmen dalam tim membantu peserta pelatihan untuk secara lebih jelas menerapkan komitmen dalam tim. Beberapa peserta semakin memahami contoh-contoh sederhana untuk mulai berkomitmen di dalam tim.
Pada sesi "menghadapi tantangan", peserta dihadapkan pada permainan yang akan menuntut perubahan dari hal yang sudah biasa dilakukan yakni menggambar menggunakan tangan yang tidak biasa. Sebagian besar peserta mengalami kesulitan pada awal menggambar, juga terdapat beberapa respon fisik yang menyertai ketidaknyamanan tersebut. Tetapi beberapa peserta menyatakan dapat menyelesaikan tantangan karena tetap berusaha menghadapi perubahan tersebut.

Sesi terakhir yakni "berubah menjadi lebih baik", peserta diberi video bagaimana menjadi individu yang mudah merespon perubahan dan berdampak positif bagi diri sendiri dan juga organisasi. Untuk mempermudah, peserta diajari penerapan metode SMART (specific, measurable, achiavable, relevant dan time-frame). Semua peserta dapat merencanakan tujuan dan tindakan yang akan dilakukan dalam menyelesaikan masalah menggunakan metode ini. Beberapa peserta yang awalnya mengalami kebingungan merasa terbantu dengan adanya metode ini.

\section{PEMBAHASAN}

Berdasarkan analisis yang dilakukan, pelatihan ketangguhan tidak dapat meningkatkan efektivitas penyelesaian masalah pada karyawan di yayasan sosial. Hasil intervensi yang dilakukan tidak sejalan dengan penelitian yang sudah ada. Menurut penelitian (Cash \& Dianne, 2011), ketangguhan memiliki korelasi positif dengan problem focused coping dan socially supported, artinya semakin tinggi tingkat ketangguhan seseorang maka semakin tinggi individu melakukan usaha (problem focused coping) dan mencari dukungan sosial (socially supported) dibandingkan melakukan penghindaran (avoidance coping). Ketangguhan juga berkorelasi negatif dengan penyelesaian masalah yang berfokus pada emosi (emotional focused 
coping) sehingga semakin tinggi tingkat ketangguhan maka semakin rendah individu dalam melakukan penyelesaian masalah yang berfokus pada emosi (emotional focused coping). Penelitian Maddi et al., (2013) juga mengatakan bahwa ketangguhan membuat individu melakukan usaha (problem solving coping), dan mencari dukungan sosial socially supportive interactions dan memiliki keuntungan terhadap diri. Namun pada pelatihan yang diterapkan, tidak memberikan perubahan atau perbedaan penyelesaian masalah melalui pelatihan ketangguhan.

Melihat hasil kategorisasi prates peserta sudah memiliki sikap penyelesaian permasalahan yang fokus terhadap masalah (problem focused coping) dan penyelesaian masalah yang berfokus pada emosi (emotional focused coping) yang tergolong tinggi sebelum pelatihan sehingga hasil paskates menjadi tidak berbeda jauh dengan hasil prates karena cenderung tetap. Sedangkan untuk penyelesaian masalah yang berfokus pada pencarian dukungan sosial (socially supported), melihat hasil kategorisasi prates, tergolong rendah dan sangat rendah sebelum dan sesudah pelatihan. Hasil pada jenis coping ini juga cenderung menetap. Untuk avoidance coping, yang diharapkan untuk mengalami penurunan nilai, ketika melihat kategorisasi peserta memiliki skor yang rendah saat prates yang berarti peserta tidak melakukan penghindaran ketika penyelesaian masalah sehingga hasil paskates menjadi tidak jauh berbeda setelah diberikan pelatihan karena cenderung menetap.

Hasil prates yang tergolong tinggi pada jenis strategi koping yang efektif diterapkan seperti problem focused coping dan tergolong rendah seperti avoidance focused coping, dapat disebabkan karena peserta memang sudah menjadi pribadi yang tangguh dan memiliki penyelesaian masalah yang efektif dalam kehidupan sehari-hari. Namun berdasarkan wawancara awal, peserta cenderung menghindari dan mengabaikan konflik atau permasalahan yang dihadapi. Keadaan tersebut membuat para peserta cenderung melakukan penyelesaian masalah yang kurang efektif dalam kehidupan pekerjaan sehingga muncul menjadi kebutuhan pelatihan. Melihat perbedaan hasil tersebut, terdapat permasalahan dalam kebenaran informasi yang diberikan oleh peserta. Istilah yang biasa dipakai dalam menjelaskan hal tesebut yakni kepatutan sosial (social desirability). Respon ini didasari keinginan untuk mendapatkan persetujuan dan penerimaan sosial yang dapat dicapai dengan cara melakukan sesuatu yang diterima oleh masyarakat (Furnham, 1986). Menurut Sjöström \& Holst, (2002), kepatutan sosial mempengaruhi kesalahan interpretasi dalam pengisian skala. Mathiowetz, (1998) juga mencatat motivasi responden turut mempengaruhi respons terhadap skala pengukuran. Peserta yang memiliki motivasi positif akan memberikan informasi yang tepat disertai bukti perilaku aktual. Oleh sebab itu, perbedaan hasil analisis skala mempengaruhi interpretasi perbedaan efektivitas pelatihan ketangguhan terhadap strategi penyelesaian masalah yang efektif pada karyawan.

Pada faktor individual, hasil analisis evaluasi perilaku menunjukkan strategi koping yang dilakukan peserta tidak efektif diakibatkan karena adanya stresor lain yang dimunculkan atau dimanifestasikan di tempat kerja. Misalnya berkaitan dengan permasalahan dalam keluarga yakni konflik dengan pasangan serta kesulitan finansial. Hal tesebut memunculkan strategi koping yang kurang sesuai karena tidak menyasar pada sumber stresornya. Beragam dan kompleksnya suatu permasalahan dari setiap peserta membuat trainer seharusnya terlebih dahulu mengungkap sumbersumber stres tersebut ketika proses pelatihan berlangsung. Namun trainer tidak mengidentifikasi sumber dari stresor yang 
dialami oleh para peserta. Oleh sebab itu, penting untuk melakukan identifikasi stresor yang dialami oleh peserta dikarenakan strategi koping akan menjadi lebih efektif jika individu mampu untuk mengenali dan mengetahui sumber stres dengan tepat meskipun gejala stres yang nampak berada pada setting lain (Rice, 1999).

Faktor lain yang turut mempengaruhi peserta untuk melakukan penyelesaian masalah secara efektif yakni adanya dukungan sosial dari lingkungan sekitar (Brannon et al., 2014). Jika dilihat dari lingkungan kerja setiap karyawan, minimnya dukungan sosial dari atasan maupun organsisasi menjadi faktor penghambar dalam penyelesaian masalah yang efektif.

Selain itu, terkait penerapan pelatihan untuk individu yang lebih tangguh dan berpengaruh terhadap efektivitas pemilihan strategi koping membutuhkan waktu dan proses yang lebih lama karena perlunya pertumbuhan pribadi dalam pengalamanpengalaman kehidupan sehingga individu dapat semakin menjadi pribadi yang tangguh (Cash \& Dianne, 2011).

Berdasarkan tabel 4 dan 5, tampak bahwa terdapat peningkatan rata-rata nilai aspek pengetahuan sebelum dan sesudah pelatihan. Selain itu, berkaitan dengan nilai signifikansi sebesar 0,002 $(<0,05)$. Hal ini menunjukkan adanya perbedaan pengetahuan pada peserta sebelum dan sesudah diberikan pelatihan. Nilai Z $(-3,093)$ menunjukkan bahwa skor paskates lebih besar daripada skor prates. Adanya peningkatan dalam skor pengetahuan disebabkan karena beragam metode yang diberikan dalam menyampaikan materi mengenai ketangguhan sehingga peserta dapat dengan mudah memahami bagaimana menjadi pribadi yang tangguh dan dapat berpengaruh dalam efektivitas penyelesaian masalah.
Selanjutnya, hasil evaluasi perilaku yang merupakan pengukuran sebagai tindak lanjut selama satu minggu setelah pelaksanaan pelatihan juga mendukung peningkatan pengetahuan peserta. Peserta diketahui mulai menunjukkan aspek-aspek dari ketangguhan yakni kontrol dan komitmen dalam melakukan penyelesaian masalah. Hasil wawancara dengan dua peserta yang dapat menerapkan kontrol ketika berhadapan dengan anak-anak atau orangtua ketika bekerja sebagai relawan. Selain itu, satu peserta lainnya juga berupaya untuk menyelesaikan permasalahan dengan melakukan perencanaan serta menerapkan konsep SMART yang diajarkan ketika menghadapi tantangan. Setelah menerapkan metode tersebut, ia mendapatkan masukan yang positif dari atasan karena dapat menyelesaikan tugas dan mampu untuk mengkomunikasikan permasalahan dengan efektif.

Peserta lain dalam wawancara juga mengungkapkan bahwa penerapan metode contoh kasus mempermudah peserta untuk membedakan dan menerapkan ketangguhan dalam berbagai konteks dan situasi permasalahan sehingga peserta dapat mengetahui beragam situasi atau keadaan dan menyesuaikan dengan penyelesaian masalah yang efektif.

\section{SIMPULAN DAN SARAN}

Berdasarkan hasil analisis yang telah dilakukan, pelatihan ketangguhan dapat meningkatkan pengetahuan peserta mengenai bagaimana menjadi pribadi yang tangguh sehingga dapat menjadi informasi untuk diterapkan dalam menyelesaikan masalah. Namun dari aspek sikap atau tendensi untuk berperilaku, pelatihan ketangguhan tidak mempengaruhi pemilihan penyelesaian masalah pada karyawan. Meskipun demikian, melihat hasil analisis secara kualitatif saat melakukan 
evaluasi tindak lanjut melalui wawancara terdapat beberapa perubahan penyelesaian masalah pada yang awalnya melakukan avoidance dan emotional focused coping menjadi seeking social support dan problem focused coping. Perubahan pengetahuan ini dipengaruhi oleh adanya penjelasan tiga aspek ketangguhan yakni kontrol, komitmen dan challenge yang diperoleh partisipan selama pelatihan melalui beragam metode yang diberikan.

Penelitian ini memberikan informasi terkait pentingnya melakukan analisis terhadap sumber-sumber stres yang dialami oleh karyawan di luar setting organisasi atau perusahaan sehingga dapat menyasar pada pemilihan strategi koping yang sesuai dengan sumber stres yang dialami. Eksplorasi terhadap sumber stresor akan membantu dalam pembentukan karakteristik pribadi yang tangguh. Berkaitan dengan organisasi terkait, dapat memaksimalkan dukungan dari lingkungan kerja untuk membantu karyawan dalam proses penyelesaian masalah yang efektif. Oleh sebab itu, salah satu bentuk dukungan yang dapat diberikan dengan melakukan sosialisasi dan mempersiapkan karyawan terhadap perubahan yang akan terjadi di dalam organisasi.

\section{DAFTAR PUSTAKA}

Algoe, S. B., \& Fredrickson, B. L. (2011).

Emotional fitness and the movement of affective science from lab to field. American Psychologist, 66(1), 35-42.

https://doi.org/10.1037/a002172 0

Anshel, M. H., Umscheid, D., \&

Brinthaupt, T. M. (2013). Effect of a combined coping skills and wellness program on perceived stress and physical energy among police emergency dispatchers: An exploratory study. Journal of Police and Criminal Psychology, 28(1), 114.

https://doi.org/10.1007/s11896012-9110-x

Bartone, P. T. (1995). A Short Hardiness Scale. Paper presented at The Third Annual Convention of The Association Psychological Society. Washington DC.

Brannon, L., Feist, J., \& Updegraff, J. A.
(2014). Health psychology: An introduction to behavior and health (Eighth). Wadsworth Cengage Learning. https://books.google.tg/books?id= uP8KWs0KHFwC\&printsec=frontco ver $\& \mathrm{hl}=\mathrm{fr} \# \mathrm{v}=$ onepage $\& \mathrm{q} \& \mathrm{f}=$ false

Carver, C. S. (1997). You want to measure coping but your protocol' too long: Consider the brief cope. International Journal of Behavioral Medicine, 4(1), 92. https://doi.org/10.1207/s1532755 8ijbm0401_6

Cash, M. L., \& Dianne, G. (2011). Cognitive hardiness, appraisal and coping: Comparing two transactional models. Journal of Managerial Psychology, 26(8), 646664. https://doi.org/10.1108/0268394 1111181752

Funder, D. C. (1991). Global Traits: A neo-allportian approach to 
personality. Psychological Science, 2(1), 31-39.

https://doi.org/10.1111/j.14679280.1991.tb00093.x

Furnham, A. (1986). Response bias, social desirability and dissimulation. Personality and Individual Differences, 7(3), 385400.

https://doi.org/10.1016/01918869(86)90014-0

Kobasa, S. C. (1982). Commitment and coping in stress resilience among lawyers. Journal of Personality and Social Psychology, 42(4).

Kobasa, S. C., Maddi, S. R., \& Kahn, S. (1982). Hardiness and health: A prospective study. In Journal of Personality and Social Psychology (Vol. 42, Issue 1, pp. 168-177). American Psychological Association. https://doi.org/10.1037/00223514.42.1.168

Lazarus, R. S., \& Folkman, S. (1984). Stress, appraisal, and coping. Springer Pub. Co.,.

Maddi, S. R. (2008). The courage and strategies of hardiness as helpful in growing despite major, disruptive stresses. In American Psychologist (Vol. 63, Issue 6, pp. 563-564).

American Psychological Association. https://doi.org/10.1037/0003066X.63.6.563

Maddi, S. R., Erwin, L. M., Carmody, C. L., Villarreal, B. J., White, M., \& Gundersen, K. K. (2013).
Relationship of hardiness, grit, and emotional intelligence to internet addiction, excessive consumer spending, and gambling. The Journal of Positive Psychology, 8(2), 128-134.

https://doi.org/10.1080/1743976 0.2012 .758306

Maddi, S. R., Harvey, R. H., Khoshaba, D. M., Fazel, M., \& Resurreccion, N. (2009). Hardiness training facilitates performance in college. The Journal of Positive Psychology, 4(6), 566-577.

https://doi.org/10.1080/1743976 0903157133

Mathiowetz, N. A. (1998). Respondent expressions of uncertainty: Data source for imputation. Public Opinion Quarterly, 62(1), 47-56. https://doi.org/10.1086/297830

Rice, P. L. (1999). Stress and health. Brooks/Cole. https://www.worldcat.org/title/st ress-and-health/oclc/300207991

Seniati, L., Yulianto, A., \& Setiadi, B. N. (2011). Psikologi eksperimen. PT. Indeks.

Sjöström, O., \& Holst, D. (2002). Validity of a questionnaire survey: Response patterns in different subgroups and the effect of social desirability. Acta Odontologica Scandinavica, 60(3), 136-140. https://doi.org/10.1080/0001635 02753740133

Taylor, S. E. (2011). Health psychology. McGraw-Hill International edition. 
Joice Mailoa E Aulia Ramdani 